\begin{tabular}{|l|l|l|}
\hline $\begin{array}{l}\text { Article Info } \\
\text { Title of Article }\end{array}$ & \multicolumn{1}{|c|}{$\begin{array}{c}\text { ReVIEW ARTICLE DERLEM MAKALESI } \\
\text { Reading The Period 1950- 1960 As }\end{array}$} \\
Geographical
\end{tabular}

\title{
Türk Sinemasında İç Göç: 1950-1960 Döneminin Coğrafi Olarak Okunması
}

\begin{abstract}
:
Migration, which is a permanent displacement movement within the borders of the country, is called internal migration. With the effect of industrialization and mechanization in agriculture, migration from rural to urban began in Turkey after 1950. Most of the migrations have been to Istanbul. As a result of migrations, there have been some positive and negative changes. These changes in the social structure and in the cities have also attracted the attention of cinema and have been the subject of films since the 1960s.

The aim of this study is to examine the migrations from rural to urban areas between the years 1950-1960 and the reflection of these migrations on cinema. Relational research method was used in the study. Within the scope of the method used, the relationship between internal migration and cinema was determined and the effect of this relationship on the films was revealed. Five films were selected to be used in the study; These are the films "Gurbet Kuşları, The Endless Road, The Bride, Wedding and Diet".

As a result of this study, it has been shown how the effects of rural-to-urban migrations experienced in Turkey in the 1950-1960 period on society and cities are reflected through the art of cinema. In addition to the deterioration of the traditional family structure, unemployment, and adaptation problems, urbanization problems such as squatting are also discussed.
\end{abstract}

KEYWORDS: Rural to urban migration, Migration movies, Cinema, 1950, 1960

${ }^{1}$ Ass. Prof., Tokat University, Faculty of Science and Letters, Department of Geography, huseyin.mertol@gop.edu.tr

${ }^{2}$ Master Degree Student, Tokat University, Faculty of Science and Letters, Department of Geography, ulkunurkoksal@gmail.com

${ }^{3}$ Asst. Prof. Dr, Samsun University, Faculty of Ecomoics, Administrative and Social Science, Department of Geography,

mucahit.yildirim@samsun.edu.tr 
ÖZ:

Ülke sınırları içerisinde yapılan kalıcı yer değiştirme hareketi olan göçlere iç göç denir. Sanayileşme ve tarımda makineleşmenin etkisiyle Türkiye'de 1950 sonrası kırdan kente göç hareketi başlamıştır. Göçlerin büyük çoğunluğu İstanbul'a olmuştur. Göçler sonucunda olumlu ve olumsuz bir takım değişimler yaşanmıştır. Toplumsal yapıda ve şehirlerde gerçekleşen bu değişimler sinemanın da ilgisini çekmiş ve 1960'lı yıllardan itibaren filmlere konu olmuştur.

Bu çalışmada amaç 1950-1960 yılları arasındaki dönemde kırdan kente gerçekleşen göçler ve bu göçlerin sinemaya yansımasının incelenmesidir. Çalışmada ilişkisel araştırma yöntemi kullanılmıştır. Kullanılan yöntem kapsamında iç göç ile sinema arasındaki ilişki belirlenmiş ve bu ilişkinin filmler üzerindeki etkisi ortaya konmuştur. Çalışmada kullanılmak üzere beş film seçilmiştir bunlar; "Gurbet Kuşları, Bitmeyen Yol, Gelin, Düğün ve Diyet" filmleridir.

$\mathrm{Bu}$ çalışmanın sonucunda Türkiye'de 1950-1960 döneminde yaşanan kırdan kente göçlerin toplum ve şehirler üzerindeki etkilerinin sinema sanatı aracılığıyla nasıl yansıtıldığı gösterilmiş̧ir. Toplumsal olarak geleneksel aile yapısının bozulması, işsizlik, uyum sorununun yanında gecekondulaşma gibi şehirleşme sorunları da ele alınmıştır.

ANAHTAR KELIMELER: Kırdan kente göç, Göç filmleri, Sinema, 1950,1960

\section{Türk Sinemasında İç Göç: 1950-1960 Döneminin Coğrafi Olarak Okunması}

\section{GİRIŞ:}

Göç insanların doğdukları veya yaşadıkları yerden başka bir alana doğru yaptıkları yer değiştirme hareketidir. Bu göç hareketleri yurtdışına olabildiği gibi ülke sınırları içerisinde de gerçekleşmektedir. Yurtdışına gerçekleşen göç hareketlerine dış göç, ülke sınırları içerisinde gerçekleşen göç hareketlerine ise iç göç denilmektedir. İç göçler kırdan kente doğru veya kentten kıra doğru gerçekleşebilir (Sürmeli, 2017). Kırdan kente doğru gerçekleşen göçler az gelişmiş bölgelerden gelişmiş bölgelere olan göç hareketleridir (Çamdalı, 2019).

Türkiye'de 1950'li yıllardan sonra iç göç hareketleri artmış ve bu göç hareketleri kırdan kente doğru olmuştur. 1948 Marshall Planı ile 240.000 traktör ülkeye girmiş (Sürmeli, 2017) ekip biçme yöntemleri değişmiş, tarımda makineleşme başlamış ve insan gücüne ihtiyaç azalmıştır. Şehirlerde istihdamın artması, ulaşım sistemlerinin gelişmesi, tarım arazilerinin miras yoluyla parçalanması ile ailenin geçimini karşılayamaması, sağlık, yaşam ve eğitim koşullarının şehirlerde daha iyi olması etkili olmuştur. Şehirleri çekici kılan bu özellikler sayesinde şehirleşme hızlanmış kır nüfusu azalırken kent nüfusu giderek artmıştır (Şen, 2014). Artan göç hareketleri ve şehirleşme olumlu olumsuz birtakım olaylar meydana getirmiştir. Meydana gelen bu olaylar hem insanlar hem de çevre üzerinde etkili olmuştur. Göçler sonucunda nüfusu artan şehirlerde çevre, gürültü, hava kirliliği, gecekondulaşma, çarpık kentleşme gibi sorunlar oluşmaya başlamıştır. Nüfusun ani bir şekilde artmasıyla istihdam olanakları yetersiz kalmış ve işsizlik baş göstermiştir (Çamdalı, 2019).

İ̧ göçler, Cumhuriyet'in etkisiyle başlayan modernleşme sürecinde toplumun yapısını ve ülke ekonomisini de belirleyen en önemli faktörlerden biridir. Kırdan kente göç eden insanlar eğlence sektörünü ve sinemayı da etkileyerek yönlendirirler. Göçmenlerin ve göç olgusunun sinemada konu edilmesi ve sorunlarına değinilmesinin nedeni göçmenlerin sanayileşme sürecinde vazgeçilemez bir faktör olmasıdır (Pişkin, 2010). Bu bağlamda Türk sineması özellikle kırdan kente göçü ele alan birçok filmi gösterime sunmuştur. Bu çalışmada yararlanılan filmler Halit Refiğ'in yönetmenliğini yaptığı Gurbet Kuşları (1964), Duygu Sarıŏglu'nun hem yönetmenliğini hem de senaristliğini yaptığı Bitmeyen Yol (1965) ve Lütfi Ö. Akad'ın yazıp yönettiği Gelin (1973), Düğün (1973) ve Diyet (1974) filmleridir. Lütfi Ö. Akad'ın filmleri aynı zamanda göç üçlemesi adıyla anılmaktadır (Velioğlu, 2014).

Yararlanılan bu filmlerde ortak özellik Anadolu'dan İstanbul'a yapılan göçlerin anlatılmasıdır. İç göç olgusunun işlendiği bu filmlerde göçün sebebi yaşanılan kırsal alanda büyük bir sorun olan yoksulluk ve işsizliktir. Özellikle 1950-1960 yılları arasındaki dönemi kapsayan iç göçler ele alınmışırı. Bu dönemde büyük şehirlerde hızlanan sanayileşme hareketi sonucunda ortaya çıkan şehirleşme ve gelişme hareketlerinin sinemadaki yansımalarına değinilmektedir. Filmlerde kullanılan öğeler kültürel, ekonomik, tarihi coğrafya ve coğrafya-mekân ilişkisi açısından ele alınmıştır. Bu dönemin anlatıldığı filmleri ele alarak kırdan kente göçün şehir ve göçmenler üzerindeki etkilerine 
değinmektedir. Yapılan çalışmada coğrafya ve sinema arasında bir ilişki kurularak göç konusunun beyaz perdeye yansıtılma biçiminin coğrafi özellikler açısından incelenmesi amaçlanmıştır.

\section{1. İç Göçün Sinemaya Yansıması}

Sinema, her zaman göç ile sıkı bir ilişki içinde olmuştur. Özellikle 2. Dünya Savaşı'nın ardından bir 'sanat' olarak hızla kurumsallaşan sinema, gerçekle daha güçlü bağlar kurmuş ve anlatılarında hayata daha fazla yer vermeye başlamıştır. Bu doğrultuda, sinemanın yaşamın önemli bir yansıması olduğu fikri yaygın olarak kabul görmüş ve halen görmektedir. Haliyle, insanlık tarihiyle yaşıt olan göç olgusunun da sinemayla ilişkisiz olması düşünülemez (Öztürk, Küçükalkan, 2019). Bu göç, postmodern ve sanayileşme sürecinde göçmenlerin yaşadığı toplumsal ve ekonomik değişimlerde sinemaya yansıtılmıştır. Yücel'e göre Postmodernizmin ana karakteri olan açık yapıt, çok seslilik, anlam çokluğu, türlerin iç içeliği, sanatçının orijinal, özgün olanın peşinde koşmaması, süreksiz, kopuk yapıt anlayışı gibi değerler ön plandadır (Yücel, 2019).

Radyo, televizyon ve diğer medya kültürü ürünleri gibi sinema da, "biz" ve "onlar" algısını şekillendirmeye yarayan materyaller sunmaktadır. Bu medya gösterileri, egemen, güçlü, güçsüz ve aciz olanı ortaya koymaktadır (Yücel, Sürmeli, 2019). Sinema; işlediği, perdeye aktardığı konularla toplumu etkileyebildiği gibi toplumun geçirdiği değişimlerden, yaşadığı olaylardan da etkilenmektedir. İzleyenleri bir düş âlemine sürükleyerek, yaşadığı gerçeklerden uzaklaştırabildiği, sorunlarını unutturarak afyonlayabildiği gibi, bireylerin, toplum sorunları konusunda daha aktif olmalarını da sağlayabilecek güçtedir sinema. Sinema ve toplum karşılıklı etkileşim içindedir. Toplumdaki değişmeler, sinemanın yapısında değişiklikler yaratırken, filmlerde işlenen konuları da etkilemektedir (Öztürk, Yücel, 2019). Bu özellikler de düşünüldüğünde göç konusunu işleyen filmlerin aynı zamanda üçüncü sinema özelliği de gösterdiği görülür. Üçüncü sinema, öncelikle sömürgeciliği ve mirasçılarını sorgular ve cinsiyet, ırk, din ve etnik kökene dayalı baskılar altında ezilenlerin kurtuluşunu hedefler. Bu yüzden; sürgün, zulüm ya da ekonomik göç nedeniyle vatanlarını terk etmek zorunda kalan insanların sorunlarını konu edinir (Öztürk, 2017).

Türkiye'de 1960'lı yıllar sinema açısından önemli gelişmelerin yaşandığı ve Yeşilçam sinemasının ortaya çıktığı dönemdir. Yeşilçam ekonomik, siyasal ve göçünde içinde yer aldığ 1 toplumsal gerçekleri sinemaya taşımıştır. Göçlerle birlikte sınıf kavramı ortaya çıkmış, bu sınıflar şehirsel mekânların değişikliğe uğramasına ve gecekondulaşmaya sebep olmuştur (Çelik, 2017). Gecekonduların ortaya çıktı̆̆ 1 dönem Türkiye'nin kentleşmeye başladığı dönemle aynı zaman diliminde yer alır. Türk sineması 1960'lı yıllardan itibaren göç ve kentleşme arasındaki ilişkiyi ele alarak meydana gelen gecekondulaşma üzerinde durmuştur (Öztürk, 2004). Göç filmlerinde yaşanılan yer, şehri olmasına rağmen lüks ve zengin semtlerin yerine alt yapı sistemlerinin olmadığı fakir semtler daha çok gösterilir. Gecekondularda devam eden geleneksel alışkanlıklara ve avlu gibi kırsal yerleşmelere ait unsurlara yer verilmektedir (Çelik, 2017).

Bu çalışmada yararlanılan göç konulu filmler Gurbet Kuşları, Bitmeyen Yol, Lütfi Ö. Akad'ın Gelin, Düğün ve Diyet filmleridir. Lütfi Ö. Akad'ın filmleri aynı zamanda göç üçlemesi adıyla anılmaktadır(Velioğlu, 2014). Filmlere konu olan göçler Anadolu'dan İstanbul'a yapılan göçlerdir. Bu göçlerin birçok sebebi olduğu gösterilmiştir. Bunlar işsizlik, geçim zorlukları, eğitim imkânlarının olmaması, bireylerin hayalleri ve zenginleşme arzusudur. Filmlerde ataerkil bir toplumun hâkim olduğu görülmektedir. Kadınların iş yaşamına çoğunlukla katılmadığı görülmüştür. Yaşam ve çalışma koşullarının zor olduğuna değinilmiştir. Çalışılan işlerinin ağır işler olduğu ve geçim zorlukları yaşanıldığı görülmektedir. Barınmak için göçmeler gecekonduları ve eski yapıları tercih etmektedirler (Kara, 2017). Şehir hayatı aile yaşamında da bir takım sorunlar meydana getirmiş̧ir. Yıllardır süregelen kültürel ve geleneksel yapı bozulmaya başlamış aile fertleri arasında anlaşmazlıklar ortaya çıkmıştır. Bu anlaşmazlıklardan en çok etkilenenlerin kadınlar olduğu görülmektedir. Kendi gelenek ve göreneklerini yaşatmaya özen gösteren aileler aynı zamanda şehir hayatına da uyum sağlamaya çalışmaktadırlar. Yaşanan maddi ve manevi zorlukların filmlere konu olması göç olgusunun olumsuz olarak algılandığını göstermektedir. İstanbul'da yaşayan yerli halkında göçmenlere karşı olumsuz tutumları olduğu görülmektedir. Yaşanan tüm bu olumsuzluklar filmlere yansıtılmıştır. Bu filmlerde İstanbul'un modernleşme ve geleneksellik arasında ikili bir yapıda olduğu görülmektedir. Modernleşmenin sosyo- kültürel alanda olduğu gibi aynı zamanda ekonomik faaliyetlerde ve kentsel politik bir olgu olan sendikalaşma faaliyetlerinde de olduğuna yer verilmiştir (Öztürk, 2004). 


\subsection{Gurbet Kuşları (1964):}

Türk sinemasında kırdan kente göç konusuna ve göçün yarattığı sorunlara gerçekçi bir şekilde değinen ilk filmdir (Tugen, 2014). Bu filmde Kahramanmaraş’tan İstanbul'a göç eden altı kişilik bir aile konu edilmiştir. İstanbul'dan "'taşı toprağı altın" diye söz edilmektedir. Filmdeki baba karakterinin söylemiyle aile "İstanbul'a şah olmaya' diye gelmiştir (Karakışlak, 2018). Büyük umutlarla göç eden aile bir tamirhane açarak işletir fakat farklı heveslere kapılan aile üyeleri zamanla tamirhaneyi kapatmak zorunda kalır. Kendilerini şehir hayatına kaptıran ailenin düzeni bozulur ve aile Maraş'a geri döner (Uğur, 2016). Bu olumsuzluklardan etkilenmeyen ve geri dönmeyen ailenin tek üyesi tıp fakültesinde okuyan küçük oğullarıdır. Filmde şehir halkının da göçmenlere karşı önyargılı olduğu görülmektedir. Kentsel mekânlardan ilk olarak İstanbul'un Anadolu'ya açılan kapısı ve göç filmlerinin simgesi olan Haydarpaşa Garı görülmektedir (Tugen, 2014). Aile gecekondulaşmış bir mahallede iki katlı geleneksel konutta yaşamaktadır. Mahallenin bozuk yolları ve gecekondular şehirsel görünümün zarar gördüğünü göstermektedir. Kente ait mekânlardan kamusal alan olarak üniversiteye, sinemaya ve eğlence mekânlarına, işyeri olarak tamirci dükkânına yer verilmiştir. Şehir görünümü olarak arka planda modern konutlar olan apartman bloklarına ve bacası tüten fabrikalara yer verilmiştir. Bu filmde göç sonucunda kentsel mekânların değişime uğradığı ve kozmopolit bir yaşam biçiminin ortaya çıktığı görülmektedir (Çelik, 2017).

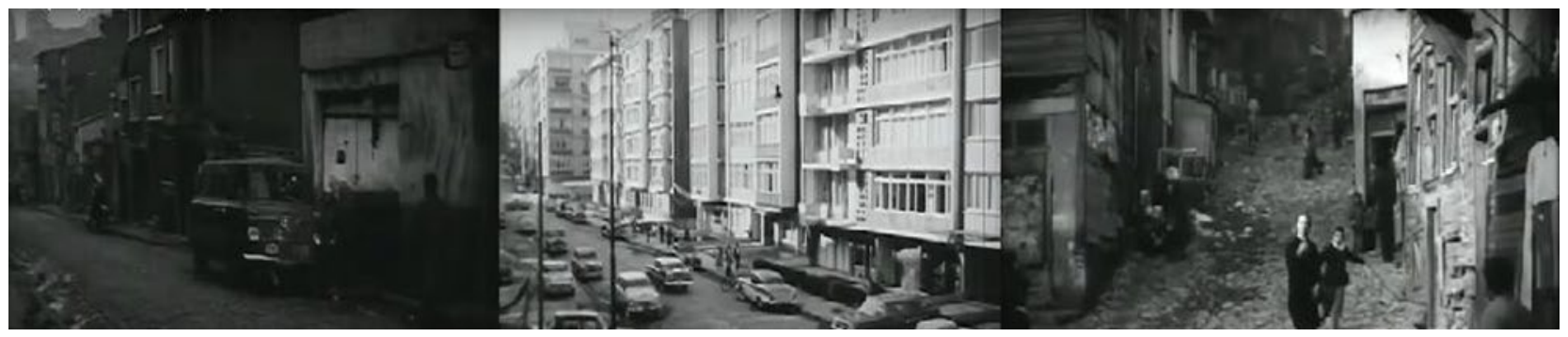

Şekil 1: Tamirci dükkânı, apartman blokları ve altyapısız gecekondu mahallesi (Gurbet Kuşları)

\subsection{Bitmeyen Yol (1995)}

Anadolu'dan İstanbul'a göçün anlatıldığı bir filmdir. Altı kişilik bir arkadaş grubunun şehirde zengin olup köye dönme hayalini ele almaktadır. Şehre uyum sağlamaya çalışan arkadaş grubunun işsizlikle ve zorlu çalışma koşullarıyla mücadele ettiği görülmektedir. Düşük ücret ve iş güvenliği sorunlarına rağmen göçmenlerin çalışmak için birbirleriyle mücadele ettiği görülmektedir. Göçmenlerin sendikaları ve sigortaları olmadığ için emeklerinin sömürüldüğüne aynı zamanda patronlarının acımasız olduğuna değinilmiştir. Filmin başkarakteri hemşerisinin gecekondu mahallesindeki evinde yaşamaktadır. Bu evde bulunan aile üyeleri konfeksiyon atölyesi ve ev işlerinde çalışmaktadır. Gecekondu mahallesinde kötü yaşam koşulları hâkimdir. Elektrik, altyapı ve yol yoktur (Çelik, Tezcan, 2017). Filmin sonunda patronlar tarafından aşağılanan başkarakterin patronu öldürerek katil olduğu görülmektedir. İstanbul'un kentsel özelliklerini yansıtan kamusal alanlardan Haydarpaşa Garı, Gülhane Parkı, İstanbul Boğazı, Haliç, Galata Köprüsü gibi öğelerin yanında semtlerinden Kadıköy ve Fatih'e de yer verilmiştir. İşyeri olarak konfeksiyon atölyesi, liman, inşaat sahası ve konut olarak geleneksel konut özelliği yansıtan gecekondu gösterilmiştir. İşçilerin bir araya geldiği kıraathane ve gecekondu mahallesi şehirsel özelliklerden çok kırsal alan özelliği gösteren mekânlardır. Limanda yalınayak çalışan işçiler, ağır işler yapan hamallar ve inşaat alanları gibi imgeler kullanılmıştır. İslam dinin simgesi olan camilere, namaza ve ezan seslerine çokça yer verilmiştir. Şehir yaşamına uyum sağlama noktasında ahlaki, dini ve aile içi bozulmalara da değinilmiştir.

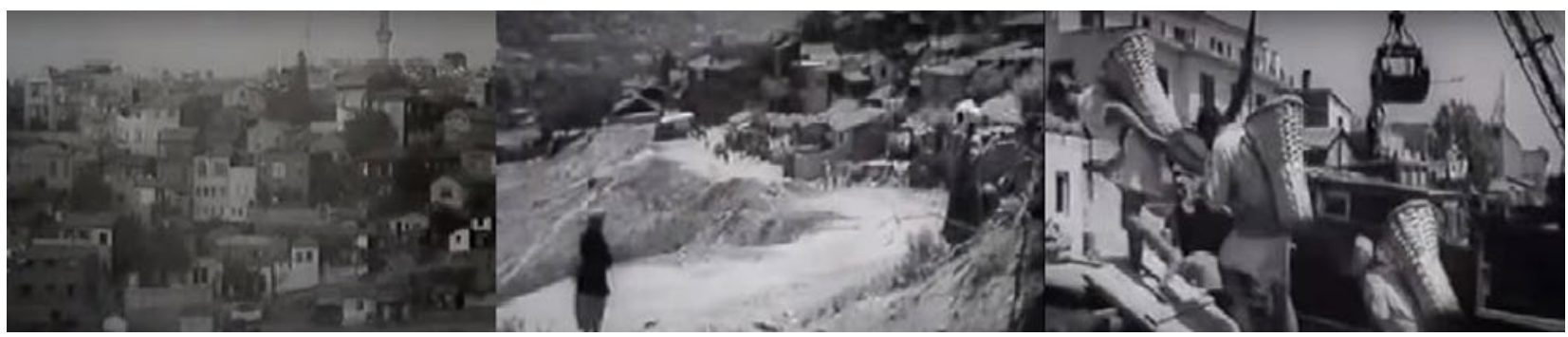


Şekil 2: Gecekondular, altyapısı ve yolu olmayan gecekondu mahallesi, limanda çalışan işçiler (Bitmeyen Yol)

\subsection{Gelin (1973)}

Gelin, Lütfi Akad'ın göç üçlemesi olarak adlandırılan eserlerinden ilkidir. Bu filmde tüm topraklarını satıp Yozgat'tan İstanbul'a göç eden bir aileyi konu etmektedir. Asıl göç nedeni mülksüzleşme ve ekonomik nedenlerdir. Ailedeki fertlerin göç sürecine bakışı birbirinden farklıdır. Kayınpeder "Orayla (Yozgat) işimiz kalmadı" diyerek dönüşün olmadığını düşünürken kayınvalide ise "'Mendil kadar yerimiz kalmalıydı" diyerek aslında göçün para kazanılıp geriye dönmek için bir araç olduğu vurgulanmaktadır (Kara, 2017). Anne, baba, çocuklar ve torunlar tüm aile üyeleri bir arada gecekonduda yaşamaktadır. Ailenin babası ve büyük oğlu bakkal işletmektedir ve zengin olma arzuları vardır. Filmi başkarakteri bir kadındır ve ailenin kü̧̈ük gelinidir. Göçün etkisiyle yaşanan olumsuzluklar, geleneksel aile yapısı, ataerkil düzen ve kapitalizmin sonucunda ortaya çıkan vahşileşmenin mağduru bu kadındır (Algan, 2018). Kadın karakterin çocuğu ailenin ihmali ve ataerkil düzen nedeniyle ölür. Bu ölüm filmde 'kurban edilme metaforu" olarak kullanılmıştır. Filmin sonunda kadının evden ayrılıp fabrikada çalışması emek gücünden başka bir şeyi kalmayan ''işçileşmiş köylüleri' göstermektedir (Kara, 2017). Şehirsel mekân olarak kamusal alanlardan Haydarpaşa tren garı, İstanbul Boğazı, Kız Kulesi, Üsküdar, Galata, hastane, bakkal, lunapark, mezarlık kullanılmıştır. Kırsal yerleşmelere benzer olarak tek katlı gecekondu ve avlusu kullanılmıştır. Filmde gecekondunun avlusundaki çitlerin üzerinden görünen apartmanlar mekânsal anlamda yapılan sınıf ayrımını somut olarak anlatmaktadır (Ateş, 2020). Ramazan ayı, sahur, oruç, namaz, dua ve kurşun dökme gibi Türk-İslam motiflerine de belli sahnelerde vurgu yapılmaktadır (Karakışlak, 2018).

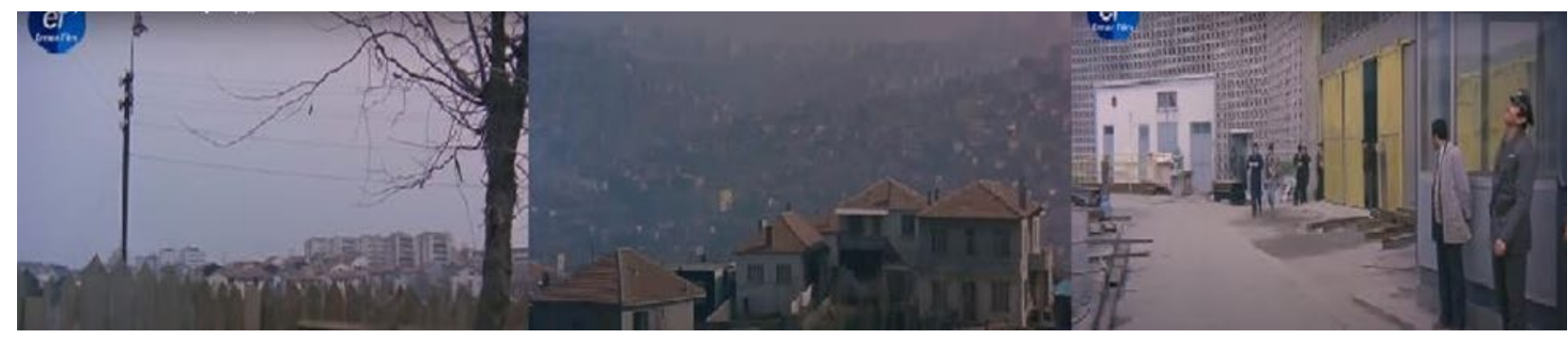

Şekil 3: Gecekondu avlusundan apartmanlar, gecekondu mahallesi ve fabrika (Gelin)

\subsection{Düğün (1973)}

Lütfi Akad'ın göç üçlemesi filmlerinden ikincisidir. Metin Erksan, Halit Refiğ, Lütfi Akad gibi sinemacılar kendilerine özgü stilleri, teknik yeterlilikleri ve biçim içerik bütünlükleriyle yazar yönetmen olarak kabul görürler (Uğur, 2017). Şanlıurfa'dan İstanbul'a göç eden altı kardeşi konu etmektedir. Hiçbir malı ve parası olmayan kardeşlerden abi seyyar satıcılık yaparak kız kardeşler fabrikada çalışarak geçimlerini sağlamaktadır. Ailenin en büyüğü olan ağabey ataerkil toplumun gereği olarak ailenin reisidir. Bu filmde de kadınlar ve yaşadıkları ön planda tutulmuştur. Abla karakteri aileyi bir arada tutmaya çalışan ve her şeye göğüs geren bir karakterdir. Abi karakteri kız kardeşlerini para hırsı yüzünden yüksek başlık parası ile uygunsuz kişilere verir. Filmde abla karakterinin söylediği " Şu İstanbul Ormanında kimseye diş geçiremeyince kardeşlerinin etini yemek kolay mı geldi?'” (Algan, 2018) sözünün sonucunda "İnsan eti yemek" gibi ağır bir tespit ortaya çıkmıştır. Birikim yapabilmek için kardeşlerini satan ve emeklerine el koyan abi için bu tanım yapılmaktadır (Kara, 2017). Ağabeyleri tarafından köle olarak satılan Hz. Yusuf'un hikâyesine de bu bağlamda yer vermiştir. Filmin başında Şanlıurfa'nın sakin görüntüsüne yer verilirken hemen ardından İstanbul'un kalabalıklığı ve karmaşası gösterilmektedir. Kamusal alan olarak sokaklar, hapishane, mezarlık, kahvehane, çarşı, pazar gibi mekânlara yer verilmiştir. İ̧̧yeri olarak kardeşlerin çalıştı̆̆ fabrika, kasap ve seyyar satıcı arabası kullanılmıştır. Yaşanılan yer bir gecekondudur. Geleneksel konut özellikleri yansıtan gecekondunun avlusu ve içinde köy firını bulunmaktadır. Gecekondunun çevresinde modern konut olan apartmanlar yer almaktadır. Sokaklarda çalışan hamallar, seyyar satıcılar, trafik yoğunluğu ve karmaşası arka planda şehrin özelliği olarak gösterilmektedir. Kültürel öğeler olarak Şanlıurfa'nın geleneksel yemeklerine de yer verilmiştir. 


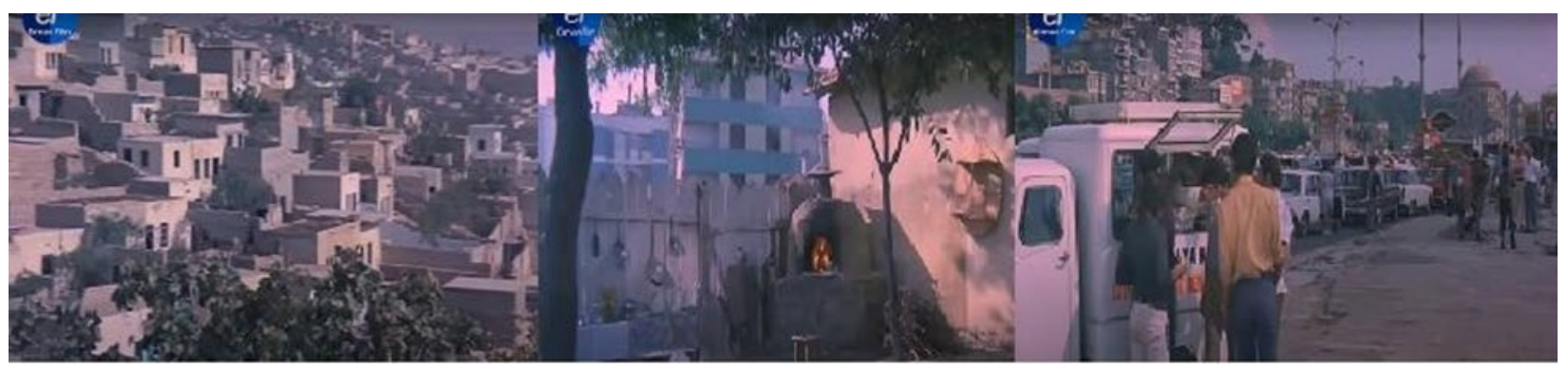

Şekil 4: Şanlıurfa'nın kırsal yerleşmeleri, gecekondu avlusu ve apartmanlar, şehir görünümü ve seyyar satıcılık yapılan araç (Düğ̈̈n)

\subsection{Diyet (1974)}

Göç üçlemesinin son filmidir. Filmde kapitalizmin bir sonucu olan işçileşme süreci anlatılmaktadır. Afyon'dan göç ederek İstanbul'da yaşamaya çalışan insanları anlatmaktadır. Bu filmde üçlemenin diğer filmlerinin aksine klostrofobik bir mekân olan ev ve avlu dışına çıkılmış hayatın ve üretimin içinde yer alınmıştır (Kara, 2017). Filmin başkarakterleri bir cıvata fabrikasında çalışmaktadır. Fabrikada çalışan işçilerin iş güvenliği yoktur ve iş kazalarının olduğu görülmektedir. Sendikalaşma mücadelelerine ve iş̧̧ilerin kendi aralarındaki çatışmalarına sık sık yer verilmiştir. Patronların acımasız olduğuna ve düşük ücretlere de değinilmiştir. Bu filmde Akad işçi olarak ve emeğini satarak yaşamanın iyi bir hayat vadetmediğine kapitalizme karşı örgütlenmenin tek çıkış yolu olduğuna vurgu yapar (Algan, 2018). İş bulamadığ için sokaklarda balon satmak durumunda kalan yaşlı baba karakteri örgütlenmenin önemini vurgulamak amacıyla ''İki birden, üç ikiden iyidir. Birleşiniz.' Hadis'i Şerif' ini kullanır (Kara, 2017). Kadın karakterin ön planda olduğu filmde ataerkil toplum düzeninin çok etkili olmadığı görülmektedir. Kamusal alanlardan hastane, kahvehane, işyeri olarak cıvata fabrikasına yer verilmiştir. Konut olarak gecekondu kullanılmaktadır. İstanbul'un şehirsel özelliklerini gösteren modern konutlar ve mekânlara da yer verilmiştir.

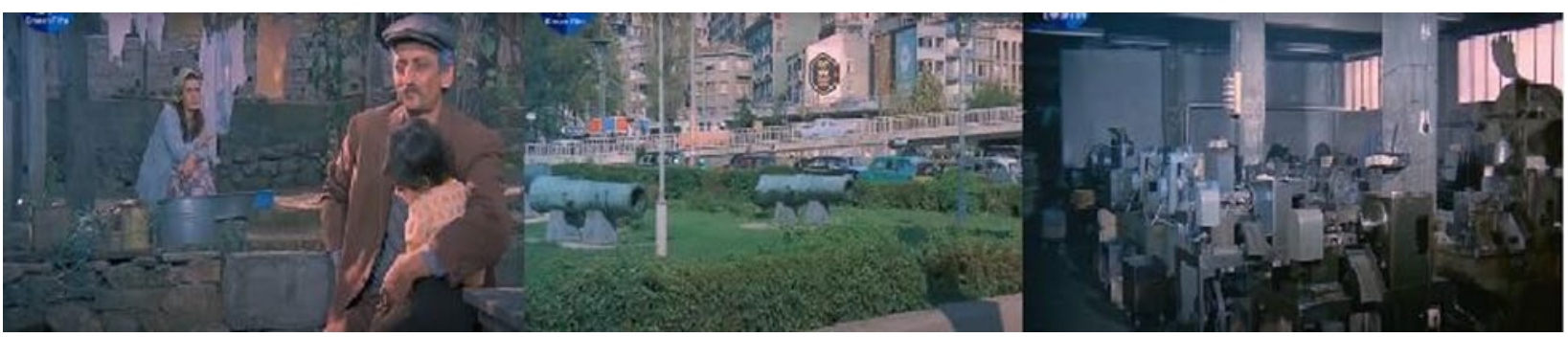

Şekil 5: Gecekondu avlusu, şehir merkezi, cıvata fabrikası (Diyet)

\section{YÖNTEM}

$\mathrm{Bu}$ çalı̧̧mada yöntem olarak ilişkisel araştırma yöntemi kullanılmıştır. İlişkisel araştırma yöntemi iki ya da daha fazla değişken arasındaki ilişskiyi ve bu ilişkinin türünü belirler. Deneysel olmayan bu araştırma yöntemi değişkenlerle ilgili tahmin yürütmek amacıyla kullanılır (akt. Christensen vd., 2010). Bu bağlamda 1950-1960 döneminde kırdan kente göçler ve bu dönemi yansıtan sinema filmleri arasında bir ilişki kurulmuştur. Örneklem olarak Bitmeyen Yol, Gurbet Kuşları, Gelin, Düğün ve Diyet filmleri seçilmiştir. Çalışma için çeşitli kaynaklar taranmıştır. Öncelikle bu dönemdeki göçleri ele alan çalışmalar incelenmiştir. Göç ve iç göçün konu edildiği makalelerle birlikte kitaplardan da yararlanılmışıır. 1950-1960 arasında kırdan kente yapılan göçlerle ilgili makaleler ve tezler kullanılmıştır. Seçilen filmler hakkında yazılan akademik ve internet makalelerinden de faydalanılmıştır. Göç konusunun sinema ile ilişkilendirilebilmesi için beş tane örnek film seçilmiştir. Bu filmler izlenilerek iç göç kavramı, coğrafi mekânlar ve imgeler incelenmiştir. Mekânlar kırsal ve kentsel özelliklerine göre nitelendirilmiştir. Şekil 6'da 1927-2012 yılları arasında kır kent nüfusunun seyri grafik haline getirilmiştir. Grafikte kırdan kente göçün etkisiyle yıllar içerisinde azalan kır nüfusuyla artan kent nüfusunun karşılaştırılması amaçlanmıştır. Şekil 7 'de filmlerin içerikleri ile ilgili tablo 
oluşturularak yaşanılan yer, göçün gerçekleştiği şehir, göç nedeni, uyum ve adaptasyon süreciyle beraber göç sonrası yaşananlar kısaca yorumlanmıştır. Şekil 8'de göç edilen iller belirtilmiş, hareket yönü ve göçün gerçekleştiği yer olan İstanbul harita üzerinde gösterilmiştir. Şekil 9'da ise göçü anlatan ve göçmenlerin İstanbul'a ulaştıkları ilk anları gösteren sahneler kullanılmıştır.

\section{BULGULAR}

Çalışmada 1950-1960 döneminde gerçekleşen kırdan kente göçler ve bu göçlerin konu edildiği filmler ele alınmıştır. $\mathrm{Bu}$ filmlerle coğrafya arasındaki ilişki göç konusu üzerinden incelenmiştir. Türkiye'de sanayileşmenin ve şehirleşmenin başladığı 1950-1960 dönemini anlatan filmler üzerinden bir ilişkilendirilme yapılmıştır. Bu şehirleşme hareketi aynı zamanda modernleşme, işçileşme, kapitalizm ve gecekondulaşma gibi kavramların Türkiye için başladığı dönemi teşkil eder. Göç sonucunda değişen kır ve kent nüfusunu göstermek için şekil 6'daki grafik kullanılmıştır.

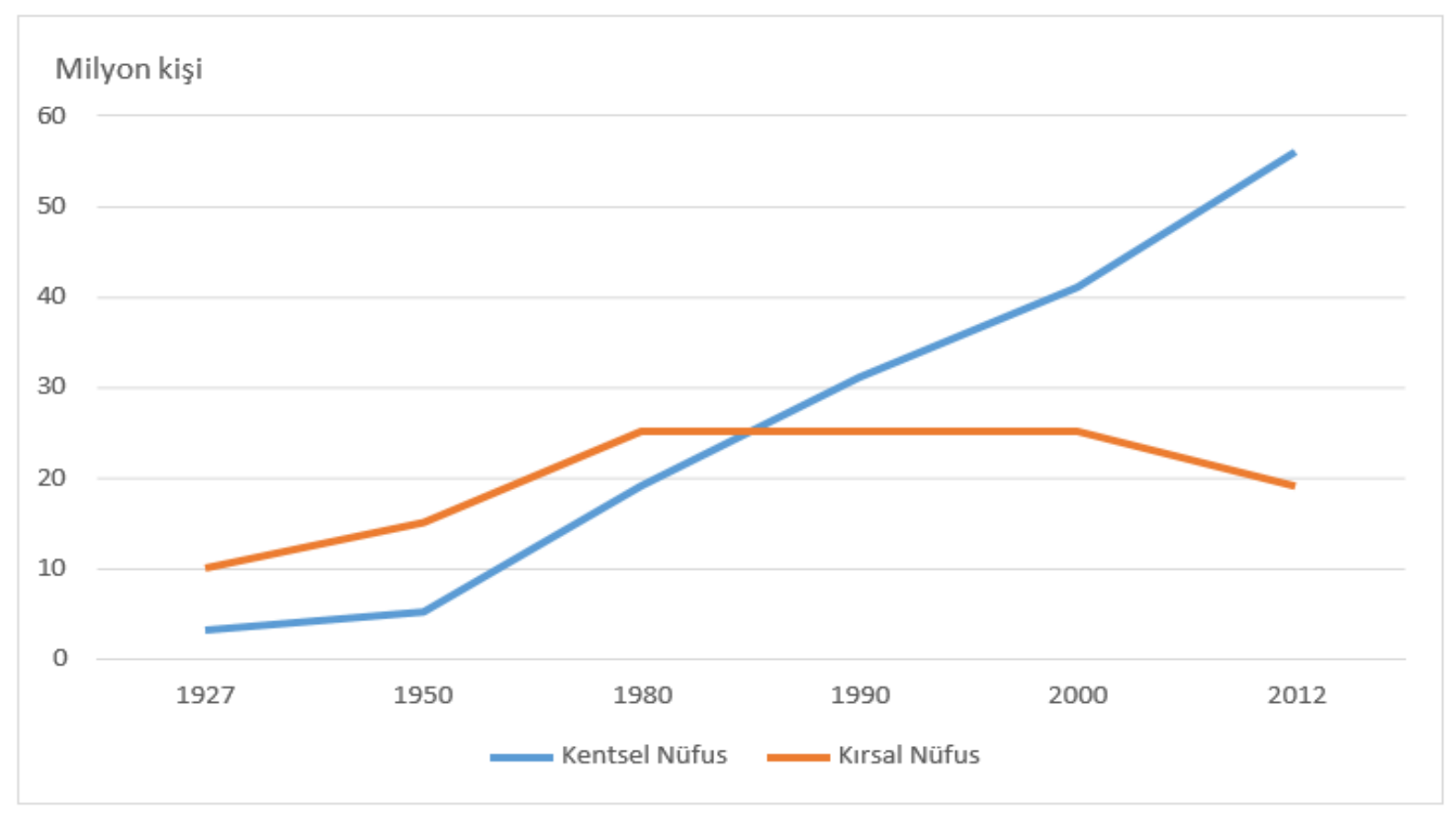

Şekil 6: Türkiye'de kentsel ve kırsal nüfusun seyri (1927-2012)

Kaynak: Doğanay, Orhan: 556

Şekil 6'daki grafiğe göre kentsel nüfus artışının 1950 yılından sonra hız kazandığı görülmektedir. Bu artışta kırdan kente göçün önemli bir etkisi vardır. Göçlerin etkisiyle kentsel nüfus büyük oranda artarken kırsal nüfusta düşüş göstermiştir. Sanayileşmenin ve şehirleşmenin etkisiyle kentsel nüfus 1950 yılından sonra sürekli bir artış görülmektedir. Sinema üzerinden bu dönem incelendiğinde toplumun sosyal, ekonomik ve politik olarak değişimlere uğradığı aynı zamanda göçün şehirsel yapı üzerinde birçok değişime yol açtığı görülmektedir.

Az gelişmiş olan coğrafyalarda geleneksel yapının etkisiyle aslında "modernleşmek" için gösterilen çabalar "batılılaşma" olarak algılanmıştır. Bu dönemde gelişmek için dönüşüm göstermek zorunda kalan insanlar arasında sosyo-ekonomik değişkenlerin etkisiyle sınıflaşma ortaya çıkmıştır. Şehirler plansız bir biçimde büyüyerek metropollere daha çok yatırım yapılmış, kırsal alanlar göz ardı edilmiş ve tarımla uğraşanlar göç etmek zorunda kalmışlardır. Göç edenler işsiz, yoksul ve topraksız kalmış olan ve daha iyi yaşam koşullarına ulaşmak isteyenlerdir(Uğur, 2016). Göçler şehirsel dokuya uymayan gecekondulaşma ile biçimsel açıdan bozulmalara, marjinal işlerin aşırı düzeyde artmasına, hemşehricilik gibi kırsala özgü dayanışma ilişkilerine, altyapının yetersiz kalmasına, siyasal yapının bozulmasına ve sosyo-kültürel olarak uyum sağlayamama gibi sorunlara neden olmuştur(Özdemir, 2012). Göçle ilgili bir diğer kavramda "Gelin" filminde vurgulanan "işşileşme" sürecidir. Göçmelerin emeklerini satmaktan başka bir kurtuluşu olmadığına değinilmiştir. Filmlerde göçmenlerin yaşamak için 
"çalışma zorunluluğu” olduğuna değinilmiştir. Bu nedenle işgüvencesi ve güvenliği olmayan, enformel sektörlerin yaygınlaştı̆̆ görülmektedir. Diyet filminde buna istinaden sendikalı olmanın iş güvencesi ve güvenliği açısından zorunlu olduğu vurgulanmaktadır (Kara, 2017).

\begin{tabular}{|c|c|c|c|c|c|c|}
\hline Filmler & $\begin{array}{l}\text { Yaşanılan } \\
\text { Kırsal } \\
\text { Yer }\end{array}$ & $\begin{array}{l}\text { Göçün } \\
\text { Gerçekleştiği } \\
\text { Yer }\end{array}$ & $\begin{array}{l}\text { Göç Etme } \\
\text { Nedeni }\end{array}$ & $\begin{array}{l}\text { Göç } \\
\text { Edilen } \\
\text { Araç }\end{array}$ & $\begin{array}{c}\text { Uyum ve } \\
\text { Adaptasyon } \\
\text { Süreci }\end{array}$ & $\begin{array}{l}\text { Göç } \\
\text { Sonrası }\end{array}$ \\
\hline $\begin{array}{l}\text { Gurbet } \\
\text { Kuşları }\end{array}$ & Kahramanmaraş & İstanbul & $\begin{array}{l}\text { Ekonomik } \\
\text { sorunlar }\end{array}$ & Tren & $\begin{array}{l}\text { Ekonomik } \\
\text { sorunlar ve } \\
\text { aile birliğinin } \\
\text { bozulması }\end{array}$ & $\begin{array}{l}\text { Uyum } \\
\text { sorunu ve } \\
\text { Maraş’a } \\
\text { dönüş }\end{array}$ \\
\hline $\begin{array}{l}\text { Bitmeyen } \\
\text { Yol }\end{array}$ & Anadolu & İstanbul & $\begin{array}{l}\text { İşsizlik ve } \\
\text { zengin olma } \\
\text { hayali }\end{array}$ & Tren & $\begin{array}{l}\text { Şehir ve iş } \\
\text { hayatına } \\
\text { uyum } \\
\text { sağlayamama }\end{array}$ & $\begin{array}{l}\text { Suçlu } \\
\text { olma }\end{array}$ \\
\hline Gelin & Yozgat & İstanbul & $\begin{array}{l}\text { Mülksüzleşme } \\
\text { ve ekonomik } \\
\text { sorunlar }\end{array}$ & Tren & $\begin{array}{l}\text { Ekonomik } \\
\text { sorunların } \\
\text { devam etmesi } \\
\text { ve aile } \\
\text { birliğinin } \\
\text { bozulması }\end{array}$ & $\begin{array}{l}\text { Ailenin } \\
\text { dağılması } \\
\text { ve } \\
\text { işçileşme }\end{array}$ \\
\hline Düğün & Şanlıurfa & İstanbul & $\begin{array}{l}\text { Yoksulluk ve } \\
\text { işsizlik }\end{array}$ & ------ & $\begin{array}{l}\text { Aile } \\
\text { birliğinin } \\
\text { bozulması } \\
\text { ve } \\
\text { ekonomik } \\
\text { sorunlar }\end{array}$ & $\begin{array}{l}\text { Aile } \\
\text { bağlarının } \\
\text { bozulmas }\end{array}$ \\
\hline Diyet & Afyonkarahisar & İstanbul & $\begin{array}{l}\text { Yoksulluk ve } \\
\text { işsizlik }\end{array}$ & ------ & $\begin{array}{l}\text { İşçileşme ve } \\
\text { ekonomik } \\
\text { sorunlar }\end{array}$ & İş kazası \\
\hline
\end{tabular}

Şekil 7: Filmler ve içerikleri

Şekil 7'deki tabloda filmlerde konu edilen göçün ana unsurları ve içeriklerinin kısaca gösterilmiştir. Göçlerin nereden nereye gerçekleştiği, göç sonrası uyum süreci, sebepleri ve sonuçları özet halinde tabloda gösterilmiştir. Şekil 7'de görüldüğü gibi yoksulluk, işsizlik ve ekonomik sorunlar göçün başlica sebeplerini oluşturmuştur. Şehre uyum sağlama sürecinde ekonomik sorunlar devam etmiş bunun yanı sıra sosyal ve toplumsal sorunlarda meydana gelmiştir. 


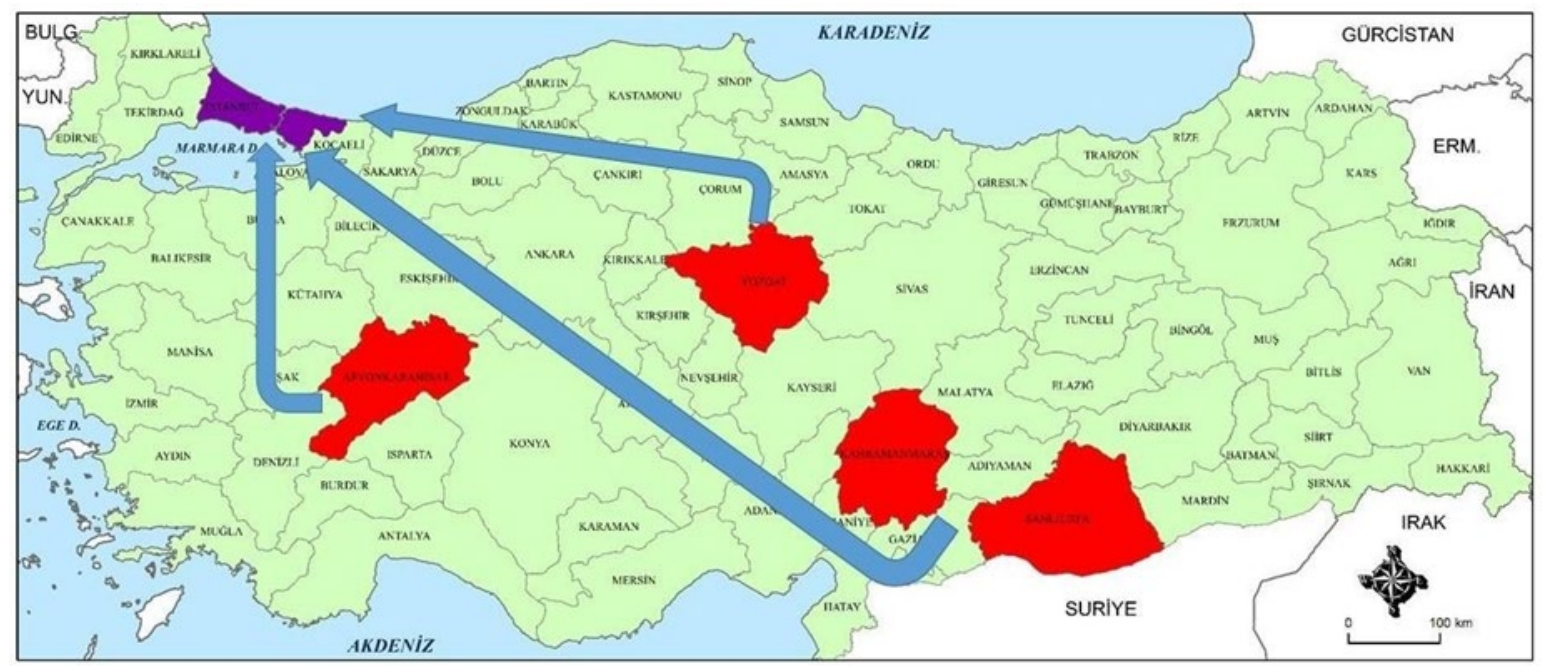

Şekil 8: Seçilmiş filmlerdeki göçlerin hareket yönü

Filmlerde bahsedilen göçlerin İstanbul'a hangi illerden yapıldığı şekil 8'deki haritada gösterilmiştir. Göçler İstanbul'a uzak olan bölgelerden gerçekleşmiştir. "Gurbet Kuşları"nda Kahramanmaraş, "Gelin"de Yozgat, "Dügün"de Şanlıurfa, "Diyet" filminde ise Afyonkarahisar ilinden İstanbul'a göç edilmiş̧ir. Bitmeyen Yol filminde ise göç edilen şehre değinilmemiştir.

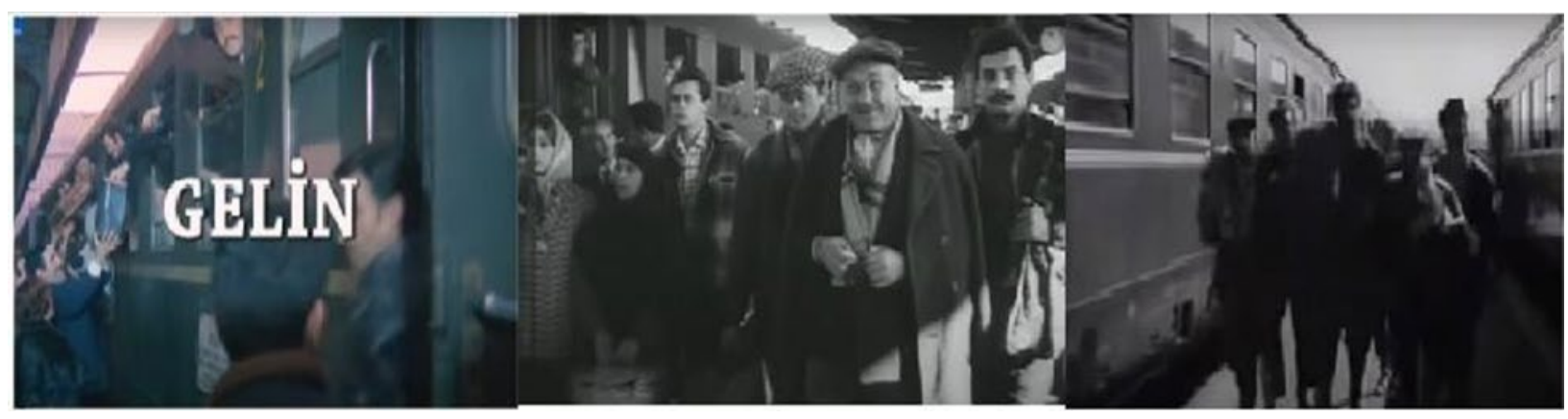

Şekil 9: Filmlerde göçmenlerin İstanbul'a ulaştığı sahneler(Gelin, Gurbet Kuşları, Bitmeyen Yol)

Şekil 9'da verilen fotoğraflarda göçmenlerin İstanbul'a ulaştığı ve göçün başlangıç noktası olan Haydarpaşa garı görülmektedir. Özellikle Gelin, Gurbet Kuşları ve Bitmeyen Yol filminde demiryolu ulaşımı ve Haydarpaşa garı göçün simgelemektedir. Gurbet kuşları filminde Haydarpaşa Garı'nda başlayan göç aynı yerde son bulmaktadır. Filmde yaşadıkları sorunlar nedeniyle İstanbul'da tutunamayan aile yine Haydarpaşa Garı'nı kullanarak memleketleri Kahramanmaraş'a geri döner. 


\section{SONUÇ:}

İnsanın yaptı̆̆ı her faaliyet ve bu faaliyetlerin çevre üzerindeki etkisi coğrafyanın konusu olabilir. Bu sebeple çalışmada coğrafyanın konusu olan kırdan kente göç ile sinema arasında bir ilişki kurulmuștur.1950-1960 dönemindeki göçler ele alınarak sinemadaki yansımaları incelenmiştir. Göçün sebeplerinden en önemlisi İstanbul'un çekiciliği ve kırsalın iticiliğidir (Pişkin, 2010). İstanbul'un sanayileşmesi ve imkânların çeşitliliği filmlerde de değinildiği üzere göçü kendisine çekmiştir. Filmlerde özellikle değinilen kırsaldaki yoksulluk ve işsizlik gibi sorunlar göçü tetiklemiş̧ir. Göçün insanlar ve şehirler üzerindeki etkisi sinema üzerinden incelendiğinde olumsuz etkilerinin daha ağır bastığı gözlenmiştir. Özellikle toplumsal açıdan bakıldığında şehir hayatına uyum sağlamaya çalışan bireylerin gerek maddi gerek manevi nedenlerle aile düzenlerinin bozulduğu görülmektedir. "'Gurbet kuşları" filminde bu olumsuzluklar göze çarpmakta İstanbul'un ve şehir hayatının zor şartlarında yitip giden göçmenlere değinilmektedir (Pişkin, 2010).

Şehirli ve köylü arasında oluşan sınıf farkı da filmlerde hem mekânsal olarak hem de sosyolojik olarak gösterilmektedir. Özellikle göçmenlerin yaşadığı gecekondu olarak adlandırılan konutlar ve çok katlı apartmanlar barınma konusunda bile sınıfsal farklar olduğunu göstermektedir. Şehrin içerisinde, şehirden soyutlanmış bir biçimde göçmenler tarafindan oluşturulmuş gecekondu mahalleri görülür. Mahalleler içerisinde göçmenlerin kendi gelenek ve göreneklerini devam ettirdiği görülmektedir. Aynı zamanda gecekondular kırsal konutlara benzemekte olup kentsel konut özelliği taşımamaktadır. Gelin ve Düğün filmlerinde kullanılan görüntülerde gecekondunun avlusundaki çitlerden görünen apartmanlar sınıf farkını gözler önüne sermektedir. Gecekondular barınmak için kullanılmasının yanı sıra sosyal faaliyetlerin ve günlük işlerin yapıldığı aynı zamanda aile içinde yapılan üretimle yürütülen ticari faaliyetlerinde gerçekleştiği yerlerdir (Ateş, 2020). Bitmeyen Yol filminde daha belirgin olan bir sorunda gecekondu mahallesinin şehirden farklı olarak yol ve altyapı yönünden yetersiz olmasıdır.

Göç üçlemesinin bir diğer filmi olan Diyet'te kapitalist sistemin meydana getirdiği işçileşme ve emek sömürüsü konuları işlenerek politik bir olgu olan sendikalaşmanın önemi vurgulanmıştır. Göçmenlerin genellikle enformel sektörlerde yer aldığı işçi sınıfının birer üyesi olduğu görülmektedir. Gurbet Kuşları ve Gelin filminde olduğu gibi kendi işyerini kurarak ekonomiye katılan göçmenlerin başarıya ulaşamaması da göçün başlıca sebeplerinden olan işsizliğin tekrar meydana gelmesine sebep olmaktadır. Toplumsal ve ekonomik yapıda meydana gelen bir değişimde kadınların bu dönemde işgücüne katılması ve istihdam edilmesidir. Lütfi Akad'ın üçlemesinden yola çıkarak bu değişimle ataerkil düzendeki kadın kimliği tanımının tartışmaya açıldığı görülmektedir. Çalışmanın sonuçları ele alındığında 1950-1960 dönemini anlatan göç filmleri coğrafya ile ilişkilendirilmiştir. Çalışmanın sonucunda coğrafyamekân, kültürel, tarihi ve ekonomik coğrafya açısından değerlendirmeler yapılmıştır.

\section{Etik Standart ile Uyumluluk}

Çıkar Çatışması: Yazarlar herhangi bir çıkar çatışmasının olmadığını beyan eder.

Etik Kurul İzni: Bu çalışma için etik kurul iznine gerek yoktur.

Finansal Destek: Finansal destek yoktur. 


\section{KAYNAKÇA:}

Algan, N. (2018,8 Ekim). Türkiye'nin görsel belleğinde bir öncü ve bir usta Lütfi Akad. http://neclaalgan.com/turkiyenin-gorsel-belleginde-bir-oncu-ve-bir-usta-lutfi-akad/

Ateş, M. (2020). Sinemada göç bağlamında sınıf, kimlik ve mekân: Ömer Lütfi Akad ve 'göç üçlemesi'. Medeniyet ve Toplum Dergisi, 4(2), 128-141.

Christensen, L. B., Johnson, R. B., Turner, L. A. (2010). Research Methods, Design and Analysis (11. bs.). Allyn and Bacon.

Çamdalı, G.D. (2019). 1950-1960 döneminde basına göre Türkiye'de göçler (Yayımlanmamışyüksek lisans tezi). Marmara Üniversitesi Sosyal Bilimler Enstitüsü, İstanbul.

Çelik, H. Z., Tezcan, S. (2017). Türk sinemasında göç temalı İstanbul filmleri üzerinden kentlerdeki mekânsal ve toplumsal değişimlerin incelenmesi. Bilecik Şeyh Edebali Üniversitesi Sosyal Bilimler Enstitüsü Dergisi, 2(2), 619636.

Çelikcan, P.(2018,18 Temmuz). Bitmeyen yol'un çaresiz yolcuları. Türk Sineması Araştırmaları. https://www.tsa.org.tr/tr/yazi/yazidetay/434/bitmeyen-yol\%E2\%80\%99un-caresiz-yolculari.

Çelik, M.F., (2017). Türk sinemasında iç göç filmlerinde birey ve mekân algısı (1960-2009). Işık Üniversitesi Sosyal Bilimler Enstitüsü, İstanbul.

Doğanay, H. ,Orhan, F. (2016). Türkiye beşeri coğrafyası (5. Bs.) . Pegem Akademi Yayıncılık Kara, M.A. (2017). Göç yazıları: kuramdan alana Türkiye’de göç. Kırmızı Çatı Yayıncılık

Karakışlak, İ. N. (2018). Türk sinemasında göç, kentleşme, gecekondulaşma ve İstanbul. International Journal of Social Science, 1(2), 279-285.

Özdemir, H. (2012). Türkiye'de iç göçler üzerine genel bir değerlendirme. Akademik bakış dergisi, 30(11), 1-18.

Öztürk, M. (2004). Türk sinemasinda gecekondular. European Journal of Turkish Studies. Social Sciences on Contemporary Turkey, (1).

Öztürk, S., Yücel, A. (2019). İran sinemasında toplumsal belleğin alegorik yansıması: ıron ısland filmi. Tarihi aydınlatan sinema. Atlas akademi, 107-108.

Öztürk, S. (2017). Sinema ve gerçeklik ilişkisinin yılmaz güney filmlerine yansıması: sürü filmi, Yalova Üniversitesi Sosyal Bilimler Dergisi, 7(15), 185-198.

Öztürk, S. (2019), Göç ve göçmen sineması bağlamında "kısa ve acısız" ve "Almanya acı vatan" filmleri üzerine karşılaştırmalı bir analiz, 8th International Vocational Schools Symposium Proceedings, cilt 1, 258- 265.

Pişkin, G. (2010). Türkiye'de göç ve Türk sineması: 1960-2009. Humanities sciences, 5(1),45-65.

Sürmeli, İ. (2017). Türkiye'de iç göçün değişim ve dönüşümü: kentten kıra yöneliş. Gazi Üniversitesi İktisadi ve İdari Bilimler Fakültesi Dergisi, (special), 275.

Şen, M. (2014). Türkiye'de iç göçlerin neden ve sonuç kapsamında incelenmesi. Çalışma ve toplum, 40(1). Tugen, B. (2014). 1960-1980 darbeleri arasında Türk sinemasında düşünce oluşumu ve filmlerin sosyolojik görünümleri. 21. Yüzyılda Eğitim ve Toplum Eğitim Bilimleri ve Sosyal Araştırmalar Dergisi, 3(7), 159-175.

Uğur, U. (2016). Gurbet kuşları filmi örneğinde iç göç olgusunun sosyolojik açıdan incelenmesi. Odü sosyal bilimler araştırmaları dergisi (odüsobiad), 6(3), 917-926.

Uğur, U. (2017). Yeni Türk sinemasında üçleme filmlerde varoluşsal izlekler. Akdeniz sanat dergisi, 2017, 76. 
Velioğlu, Ç. (2014). Türk sinemasında dış göçle birlikte oluşan kültürel değişimin bir öğe olarak dinin temsili: Berlin in Berlin. Akdeniz iletişim, (21).

Yücel, A. (2019). Andy Warholl çalışmalarının metinler arasılık bağlamında incelenmesi, Ordu Üniversitesi Sosyal Bilimler Araştırmaları Dergisi (odüsobiad), cilt:9, sayı:1, ordu(3).

Yücel A., Sürmeli Z.(2019) - “ Sinemada oryantalist ve oksidentalist söylem: “duvara karşı” filmi örneği “, idil dergisi, cilt:8, say1: 54, İstanbul, (112). 